\title{
From Engines for Conflict into Engines for Sustainable Development: The Potential of International Law to Address Predatory Exploitation of Natural Resources in Situations of Internal Armed Conflict
}

\author{
Daniëlla Dam-de Jong* \\ Doctoral Candidate and Lecturer, Grotius Centre for International Legal Studies \\ Leiden University, Leiden, The Netherlands
}

\begin{abstract}
Since the end of the Cold War, natural resources have proven an adequate replacement for external funding of armed conflicts. The prospects for parties to an armed conflict to gain 'easy' profits from resource exploitation encourage these parties to engage in predatory practices that are highly detrimental to environmental conservation. The environmental degradation caused by predatory resource exploitation by parties to an armed conflict also severely hampers efforts towards the post-conflict reconstruction of a State. Environmental degradation of land may spark new tensions in the fragile phase of post-conflict reconstruction. In addition, natural resources are an important engine to restart the economy of a war-torn State after the conflict has come to an end. If the resources are severely degraded or even exhausted as a consequence of their exploitation during armed conflict, it becomes even more difficult to kick-start the economy of a State emerging from conflict. This article argues that current international law is not sufficiently equipped to deal with these challenges. The existing regulatory framework is fragmented and imprecise. It is only through case specific responses under Security Council sanctions regimes that the challenges are currently addressed.
\end{abstract}

Keywords

natural resources; armed conflict; resource curse; environment; sanctions

\section{Introduction}

The exploitation of natural resources in order to finance an armed conflict is today one of the most prevalent causes of environmental damage during armed conflict. ${ }^{1}$ Extensive logging by all parties to the armed conflict in Cambodia, for example,

\footnotetext{
*) LL.M., M.A.The author expresses gratitude to Prof. Nico Schrijver, Dr. Erik Koppe and the anonymous reviewer for providing useful comments on a draft of this paper.

1) Cf. K. Hulme, 'Environmental Security: Implications for International Law', 19 Yearbook of International Environmental Law (Oxford University Press, Oxford, 2008) p. 15.
} 
significantly diminished the country's forest cover. ${ }^{2}$ Likewise, highly organised and systematic exploitation activities within and around United Nations Educational, Scientific and Cultural Organization (UNESCO) World Heritage sites in the Democratic Republic of the Congo (DR Congo), including ivory poaching, logging and mining, have posed a significant threat to the integrity of these biodiversity reserves. ${ }^{3}$ Similarly, substantial diamond mining during the conflict in Sierra Leone caused extensive land degradation. Exhausted mining sites were not rehabilitated, resulting in severe environmental degradation. ${ }^{4}$

Although unsustainable patterns of resource exploitation are not specific to the situation of armed conflict only, the examples above show that resource exploitation during an armed conflict poses a special threat to the environment. The prospects for parties to an armed conflict to gain 'easy' profits from resource exploitation, either in order to finance their armed struggle or for their personal benefit, encourage these parties to resort to destructive exploitation methods that are highly detrimental to environmental conservation.

This article explores the issue of predatory behaviour by parties to an armed conflict ${ }^{5}$ which causes severe damage to the very natural resources that are the basis for development. The principal question addressed concerns the role that international law should play in addressing this problem. This article argues that international law should first and foremost provide an adequate legal framework to govern the exploitation of natural resources during armed conflict. This is currently not the case. Rather, the existing international legal framework is both fragmented and imprecise. It is posited that this is problematic because it provides parties to an armed conflict with possibilities to bypass the few rules that are in place.

A second role that international law should play is to provide structural solutions to break the link between natural resources and armed conflict. It is argued that this is an essential part of the process of conflict resolution and peace-building. This article focuses on the role of the Security Council in addressing these issues. Sanctions have been the prevalent tool used by the Security Council to address predatory resource exploitation in recent armed conflicts. ${ }^{6}$

2) For more details on the links between logging and the armed conflict in Cambodia, see P. Le Billon and S. Springer, 'Between War and Peace: Violence and Accommodation in the Cambodian Logging Sector', in W. de Jong, D. Donovan and K. Abe (eds.), Extreme Conflict and Tropical Forests (Springer, New York, 2007) pp. 17-36.

3) Interim report of the Panel of Experts on the Illegal Exploitation of Natural Resources and Other Forms of Wealth of the Democratic Republic of the Congo, UN Doc. S/2002/565, paras. 50 and 52.

4) See UNEP, Sierra Leone: Environment, Conflict and Peacebuilding Assessment, February 2010, p. 45 .

5) Ballentine and Nitzschke refer in this regard to 'resource predation'. See K. Ballentine and H. Nitzschke (eds.), Profiting from Peace: Managing the Resource Dimensions of Civil War (Lynne Rienner Publishers, Boulder 2005) p. 2.

6) Direct commodity sanctions have been imposed inter alia in the conflicts in Angola, Sierra Leone, Liberia and Côte d'Ivoire, while ancillary sanctions (asset freezes and travel bans against 
These sanctions regimes have increasingly moved away from direct crisis management to more systematic approaches aimed at breaking the link between natural resources and armed conflict. This article embraces this development and argues in favour of an enhanced role for the Security Council in this regard.

The following section discusses the role of natural resources in fuelling armed conflict. Sections 3 and 4 examine the regulatory framework for the exploitation of natural resources during armed conflict. In section 5 this article examines the structural approach adopted by the Security Council in some of its recent sanctions regimes aimed at breaking the link between natural resources and armed conflict. Since most of the armed conflicts in which predatory resource exploitation take place are internal in nature, this article focuses exclusively on these conflicts.

\section{The Role of Natural Resources in Fuelling Armed Conflicts}

Natural resources are at the heart of many present-day armed conflicts. Examples include the conflicts in Cambodia, Angola, Sierra Leone and Liberia in the $1990 \mathrm{~s}$ and the ongoing conflicts in the DR Congo and Côte d'Ivoire. Even if these conflicts are not strictly motivated by the drive to obtain access to lucrative natural resources, natural resources have played a major role in sustaining these armed conflicts. ${ }^{7}$ In this way, they have helped shape the dynamics of these conflicts.

In some cases, natural resources have proven to be an adequate replacement for Cold War funding by the major superpowers. This may be illustrated by the armed conflict in Cambodia between 1979 and 1991. For a long time, this conflict was funded through the support of other States. The Soviet Union sponsored the government side, while China and the United States funded the ousted Khmer Rouge regime. It was only after these revenues had started to dry up that natural resources came into the picture. Both the government and the Khmer Rouge started logging timber to fund their armed struggle. ${ }^{8}$ The conflict in Angola between 1975 and 2002 is also illustrative. During the Cold War, the Angolan government received funding from the Soviet Union and Cuba, while the opposing National Union for the Total Independence of Angola (UNITA) received funding from the United States, France and South Africa. From the early 1990 os on, the government switched to oil, while UNITA discovered diamonds as a new source of revenue. ${ }^{9}$

persons implicated in predatory resource exploitation) have been imposed in the conflict within the DR Congo.

7) See e.g. K. Ballentine and J. Sherman (eds.), The Political Economy of Armed Conflict: Beyond Greed and Grievance (Lynne Rienner Publishers, Boulder 2003); Ballentine and Nitzschke (eds.), supra note 5 .

8) See Le Billon and Springer, supra note 2, pp. 17-36.

9) See Ballentine and Sherman, supra note 7, pp. 23-24. 
In other cases, the role of natural resources during the conflict evolved from a mere source of funding into a motivation to continue fighting. Gaining control over the Sierra Leonean diamond fields, for example, became one of the principal aims of the opposing Armed Forces Revolutionary Council (AFRC) and the Revolutionary United Front (RUF) in the conflict that raged through Sierra Leone in the 199os, especially in the final phase of the conflict. ${ }^{10}$ After the conflict, the leaders of both armed groups were charged before the Special Court for Sierra Leone for sharing a "common plan, purpose or design (joint criminal enterprise) which was to take any actions necessary to gain and exercise political power and control over the territory of Sierra Leone, in particular the diamond mining areas". ${ }^{11}$ Likewise, obtaining access to lucrative minerals in the DR Congo continues to be a motivation for armed groups fighting in the eastern provinces of the DR Congo today. ${ }^{12}$

Natural resource revenues constitute an important source of income for rebel groups and the government alike. In the conflict in the DR Congo, for example, minerals provide both the rebel groups and the government with an important source of income to fund their military campaign. ${ }^{13}$ Likewise, in the conflict in Côte d'Ivoire, diamonds provided the rebel groups with income, while the government funded its military campaign through cocoa and coffee. ${ }^{14}$ Other examples include Angola (oil and diamonds), Cambodia (timber and gemstones) and Sierra Leone (diamonds). Although it is often difficult to establish the extent to which resource exploitation by States is used directly to fund an armed conflict, reports by relevant UN Panels of Experts have demonstrated the existence of a link between resource revenues and military expenditure. In the case of Côte d'Ivoire, for example, the UN Group of Experts established a clear link between

10) Report of the Sierra Leone Truth and Reconciliation Commission, Witness to Truth, Volume 3b: Chapter 1: Mineral Resources, their Use and their Impact on the Conflict and the Country, available through < www.sierra-leone.org/TRCDocuments.html $>$, visited on 31 July 2012.

11) See the indictment in the case of The Prosecutor v. Sesay, Kallon and Gbao (RUF Case), Case No. SCSL-2004-15-PT, para. 36; and the indictment in the case of The Prosecutor v. Brima, Kamara and Kanu (AFRC Case), Case No. SCSL-2004-65-PT, para. 33, both before the Special Court for Sierra Leone.

12) See the Final Report of the Group of Experts on the Democratic Republic of the Congo prepared pursuant to paragraph 6 of Security Council resolution 1896 (2009), UN Doc. S/2010/596 of 29 November 2010, p. 76, where the Group of Experts comes to the conclusion that "economic motivations are increasingly driving a significant portion of armed actors".

13) See the Report of the Panel of Experts on the Illegal Exploitation of Natural Resources and Other Forms of Wealth of the Democratic Republic of the Congo, UN Doc. S/2001/357 of 12 April 2001 and the Addendum to the Report, UN Doc. S/2001/1072 of 13 November 2001.

14) Midterm report of the Group of Experts submitted in accordance with paragraph 11 of Security Council resolution 1842 (2008), UN Doc. S/2009/188 of 8 April 2009; Final report of the Group of Experts on Côte d'Ivoire, prepared in accordance with paragraph 14 of Security Council Resolution 1980 (2011), UN Doc. S/2012/196 of 14 April 2012. 
natural resources, in particular cocoa, and extra-budgetary military spending by the Ivorian government. ${ }^{15}$

Resource exploitation by parties to an armed conflict is not carried out solely to obtain revenues to fund the armed conflict. There are also cases in which natural resource exploitation is undertaken for the personal benefit of individuals. A report of the Group of Experts on the DR Congo, for example, reveals that exploitation activities are carried out both by armed groups and by factions within the Congolese army for their personal enrichment. ${ }^{16}$ Thus, it is often difficult or even impossible to make neat distinctions between resource exploitation for the purpose of funding an armed conflict and for the personal benefit of members of armed groups. The two purposes are often inextricably linked.

While all of these activities keep the armed conflict ongoing, both the actors involved and their motivations have implications for the rules that apply to specific instances of predatory resource exploitation. With this in mind, the following sections examine the existing legal framework for the exploitation of natural resources during armed conflict.

\section{General Remarks on the Applicability of Various Sets of Rules}

In order to properly understand the legal framework governing the exploitation of natural resources during armed conflict, this section discusses the interplay between the different fields of international law that shape the legal framework. These fields include international humanitarian, environmental, human rights and general international law.

First of all, international humanitarian law, the law which is designed specifically to regulate the situation of armed conflict, provides two basic rules. Protection of the environment and natural resources under this field of international law is provided primarily through provisions on the protection of civilian objects and of property. The most relevant provisions relate to the protection of objects indispensable to the survival of the civilian population (Article 14 of Additional Protocol II); and the prohibition of pillage (Article $4(2)(\mathrm{g})$ of Additional Protocol II to the Geneva Conventions). Moreover, additional protection is provided through the

15) See e.g. the Report of the Group of Experts submitted in accordance with paragraph 7 of resolution 1584 (2005), UN Doc. S/2005/699, paras. 22-42. See also the Final Report of the Group of Experts on Côte d'voire, prepared in accordance with paragraph 14 of Security Council resolution 1980 (2011), supra note 14, paras. 92-95 for a link between natural resources and violations of the arms embargo by the Ivorian government.

16) See the Final Report of the Group of Experts on the Democratic Republic of the Congo prepared pursuant to paragraph 6 of Security Council resolution 1896 (2009), supra note 12, pp. $47-76$. 
prohibition on the destruction or seizure of the property of the adversary, derived from Article 23(g) of the 1907 Hague Regulations. This prohibition is not expressly codified for internal armed conflicts, but its application to these conflicts may be derived from international criminal law (Article 8(2)(e)(xii) of the 2002 International Criminal Court (ICC) Statute). ${ }^{17}$

In addition, international environmental, human rights and general international law, although not designed specifically to deal with situations of armed conflict, also provide relevant rules. ${ }^{18}$ These fields of international law apply at all times, including during armed conflict. Yet, in those cases where international humanitarian law provides relevant rules, international environmental, human rights and general international law are set aside. This is due to the status of international humanitarian law as the prevailing lex specialis during an armed conflict. ${ }^{19}$

However, this is not to say that these fields of international law lose their relevance entirely. Where international humanitarian law does contain relevant rules, international environmental, human rights and general international law continue to play a role in the background as other rules of international law which must be taken into account in the interpretation of international humanitarian law provisions on the basis of Article 31(1) and (3)(c) of the Vienna Convention on the Law of Treaties. ${ }^{20}$ On the basis of Article $31(1)$ of the Vienna Convention, international environmental, human rights and general international law can be taken into account in order to clarify the ordinary meaning of the terms of international humanitarian law provisions. In addition, Article $31(3)(c)$ of the Vienna Convention prescribes that treaty provisions are to be interpreted in the light of other rules of international law applicable between the parties to the treaty.

17) A more detailed discussion of these provisions follows.

18) The recently adopted ILC articles on the effects of armed conflict on treaties formulate a presumption of continued applicability of international environmental and human rights treaties. See Draft articles on the effects of armed conflicts on treaties, with commentaries, adopted at the 63rd session of the ILC (2011).

19) On the interplay between international humanitarian law and other fields of law during armed conflicts, see the following documents related to the ILC study on the effects of armed conflict on treaties: Second report on the effects of armed conflicts on treaties by Ian Brownlie, Special Rapporteur, UN Doc. A/CN.4/570, 16 June 2006, para. 41 and the Third report on the effects of armed conflicts on treaties by Ian Brownlie, Special Rapporteur, UN Doc. A/CN.4/578, paras. 29-31 and 49-55; Effects of Armed Conflict on Treaties, Comments and information received from Governments, UN Doc. A/CN.4/622, 15 March 2010; the Memorandum of the UN Secretariat on the Effect of Armed Conflict on Treaties: an Examination of Practice and Doctrine, UN Doc. A/ CN.4/550 of 1 February 2005 .

20) Article 31(1) of the Vienna Convention provides that "[a] treaty shall be interpreted in good faith in accordance with the ordinary meaning to be given to the terms of the treaty in their context and in the light of its object and purpose". Article $31(3)(\mathrm{c})$ determines that, "[t]here shall be taken into account, together with the context: ... any relevant rules of international law applicable in the relations between the parties". 
Relevant rules from international environmental, human rights and general international law include the principle of sustainable development and related principles, such as sustainable use, equity and good governance. ${ }^{21}$ Another important principle, derived from state sovereignty and the right of peoples to selfdetermination, is the principle of permanent sovereignty over natural resources and the corresponding obligation to use natural resources for national development and the well-being of the people. This principle has found expression in the landmark Declaration on Permanent Sovereignty over Natural Resources and has also been laid down in identical Articles 1(2) of the 1966 International Covenant on Civil and Political Rights (ICCPR) and International Covenant on Economic, Social and Cultural Rights (ICESCR). ${ }^{22}$ This provision formulates a right for peoples to freely dispose of their natural resources as well as a prohibition to deprive peoples of their means of subsistence. This prohibition applies in all circumstances.

\section{Legal Framework for Resource Exploitation during Armed Conflict}

The current section examines the legal framework for the exploitation of natural resources during internal armed conflicts. The objectives of this section are to determine the extent to which the current legal framework addresses the issue of predatory resource exploitation and to establish the weaknesses of the current framework.

For this purpose, this section focuses first of all on the basic rules of international humanitarian law relating to the exploitation of natural resources that apply to all parties to an internal armed conflict, whether rebel groups or the national army. In addition, the current section examines the extent to which peacetime law closes the gaps left open by the international humanitarian law rules.

\subsection{International Humanitarian Law}

International humanitarian law does not contain specialised rules governing the exploitation of natural resources. Nonetheless, it does contain some rules that are

21) See in this regard the ILA New Delhi Declaration of Principles of International Law Relating to Sustainable Development, UN Doc. A/57/329 of 31 August 2002, which distinguishes seven principles relating to sustainable development. For a recent analysis of international case-law relevant to the principles of sustainable development, see the 2010 Hague Conference Report of the ILA Committee on International Law on Sustainable Development, available through $<$ www .ila-hq.org>, visited on 26 March 2012.

22) For the Declaration on Permanent Sovereignty over Natural Resources, see UN General Assembly Resolution 1803 (XVII), adopted on 14 December 1962. For a detailed analysis of the genesis of this principle as well as its contents, see N.J. Schrijver, Sovereignty over Natural Resources: Balancing Rights and Duties (Cambridge University Press, Cambridge, 1997). 
relevant to the issue of natural resource exploitation. These are the prohibition on the taking or destruction of objects indispensable to the survival of the civilian population (Article 14(2) of Additional Protocol II); the prohibition of pillage (Article 4(2)(g) of Additional Protocol II) and the prohibition on the seizure or destruction of the property of the adversary (derived from Article 23(g) of the 1907 Hague Regulations). It is posited in this regard that natural resources may constitute property, since they are capable of ownership.

It is to be noted that the prohibition on taking or destroying objects indispensable to the survival of the civilian population and the prohibition of pillage are laid down in Additional Protocol $\mathrm{II}^{23}$ which is applicable to internal armed conflicts between government troops on the one side and one or more organised armed groups on the other. Internal armed conflicts which do not involve government armed forces or otherwise do not reach the threshold set by Additional Protocol II are governed by the rules formulated in common Article 3 of the Geneva Conventions ${ }^{24}$ and by customary international law.

In this regard, it should be noted that Article 3 contains an obligation of humane treatment. This obligation may be interpreted as a prohibition on depriving the population of their basic needs for survival. It thus resembles the prohibition contained in Article 14 of Additional Protocol II. In addition, the prohibition of pillage has attained the status of customary international law. ${ }^{25}$ As such, it also applies to armed conflicts that do not satisfy the criteria set by Additional Protocol II. Thus, in practice, the regulatory regime for conflicts reaching the threshold of Additional Protocol II and those that do not, is quite similar.

23) In this regard, Article 4(2)(g) of Additional Protocol II to the Geneva Conventions, adopted on 8 June 1977 (1125 UNTS 609), determines that pillage against persons who do not take a direct part or who have ceased to take part in hostilities remains prohibited at any time and in any place whatsoever. Article 14(2) of Additional Protocol II stipulates that "[s]tarvation of civilians as a method of combat is prohibited. It is therefore prohibited to attack, destroy, remove or render useless, for that purpose, objects indispensable to the survival of the civilian population, such as foodstuffs, agricultural areas for the production of foodstuffs, crops, livestock, drinking water installations and supplies and irrigation works." Both provisions are discussed in more detail in the following sections.

24) Article 3, which is common to all four Geneva Conventions, adopted on 12 August 1949 (75 UNTS 287), contains a set of minimum rules applicable in internal armed conflicts aimed at protecting the human dignity of persons not taking part in hostilities.

25) Both the Appeals Chamber of the ICTY and the Special Court for Sierra Leone have expressly held the prohibition of pillage to be part of customary law applicable to noninternational armed conflict. Hadzihasanovic, Alagic and Kubura (IT-01-47), ICTY, 11 March 2005, Decision on Joint Defence Interlocutory Appeal of Trial Chamber Decision on Rule 98bis Motions for Acquittal, para. 37; The Prosecutor v. Moinina Fofana and Allieu Kondewa, Special Court for Sierra Leone, 28 May 2008, Appeals Chamber Judgment, para. 390. 
4.1.1. Prohibition to Take or Destroy Objects Indispensable to the Survival of the Civilian Population

Article 14 of Additional Protocol II prohibits parties to an armed conflict to "attack, destroy, remove or render useless" objects that may be considered indispensable to the survival of the population. This prohibition is subject to the overarching prohibition on starving the civilian population. This implies that the prohibition on taking or destroying objects that are indispensable to the civilian population requires some form of intent on behalf of the perpetrator to do harm to the civilian population. Arguably, this intent may take the form of direct intent or of reckless disregard by a party to an armed conflict for the consequences of its actions.

Article 14 of Additional Protocol II provides a safety net for the population of a State mixed up in an internal armed conflict, which secures their right to retain access to the basic needs for survival. The provision is generally understood to provide protection to parts of the environment that supply the population with foodstuffs and other primary goods necessary for their survival. ${ }^{26}$ Thus, in the first instance it prohibits practices like the targeting of water supply systems and the destruction of crops, as, for example, reportedly done by the rebel group RUF during the conflict in Sierra Leone. ${ }^{27}$

A question of interest in this regard is whether and to what extent the prohibition covers valuable natural resources. Can valuable natural resources be considered 'indispensable to the survival of the population'? Although this seems far-fetched at first blush, it must be remembered that many civilians in conflict regions are highly dependent on particular natural resources to generate a basic income. In fact, it seems that the dependency of the local population on artisanal mining in the DR Congo constituted one of the principal reasons for the Security Council to abstain from imposing commodity sanctions to curb the trade in natural resources originating from the DR Congo. ${ }^{28}$

It is posited here that the phrase 'objects indispensable to the survival of the civilian population' in Article 14 of Additional Protocol II should be interpreted extensively to cover natural resources that provide a basic income for the local population. This can be achieved through an interpretation of Article 14 of Additional Protocol II in the light of identical Article 1(2) of the ICESCR and

26) Article 14 of Additional Protocol II contains a non-exhaustive list of objects which are considered indispensable to the survival of the population, including "food-stuffs, agricultural areas for the production of food-stuffs, crops, livestock, drinking water installations and supplies and irrigation works".

27) UNEP, Sierra Leone, Environment, Conflict and Peacebuilding Assessment, Technical Report, February 2010, p. 45.

28) A report prepared by the Secretary-General had warned against the negative impacts of such sanctions on the local population. See the Report of the Secretary-General pursuant to paragraph 8 of resolution 1698 (2006) concerning the Democratic Republic of the Congo, UN Doc. S/2007/68 of 8 February 2007, paras. 62-63. 
the ICCPR. This provision determines that a people may not be deprived of its own means of subsistence. An interpretation of Article 14 of Additional Protocol II in light of Article 1(2) of the ICESCR and the ICCPR would therefore extend the protection provided by the provision to all objects which provide the population with the means of subsistence, including particular natural resources that generate a basic income for the local population. Following this interpretation, parties to an armed conflict may, under certain circumstances, be prohibited from cutting-off the civilian population from the mining sites or forests under their control.

\subsubsection{Prohibition of Pillage}

Article 4(2)(g) of Additional Protocol II formulates a prohibition of pillage. This prohibition traditionally applies to acts of theft, either by individual soldiers or through forms of organised plundering. ${ }^{29}$ The provision is sufficiently broad to capture all types of natural resources, whether state-owned or privately-held; extracted natural resources or forests and mines; as well as rights relating to the exploitation of natural resources, such as concessions. ${ }^{30}$

Nonetheless, the prohibition contains some important restrictions. These restrictions are not explicit in the provision, but may be derived from international criminal law. The Elements of Crime that define the crimes listed in the ICC Statute restrict pillage to appropriation for private or personal use. ${ }^{31}$ In section 2 above it was argued that the exploitation of natural resources by parties to an armed conflict may serve two purposes. Natural resources are either exploited to fund an armed conflict or for the personal benefit of individuals. In the latter case, the requirement of appropriation for private or personal use is easily satisfied. Thus, the prohibition of pillage may be said to apply to acts of predatory resource exploitation by members of rebel groups or the national army for their personal gain.

It is also within this context that the prohibition of pillage was applied by the International Court of Justice (ICJ) in the case of the DR Congo against Uganda.

29) See the Commentary to the Additional Protocols, p. 1376; and G. Carducci, 'Pillage', in R. Bernhardt, Encyclopedia of Public International Law, Max Planck Institute for Comparative Public Law and International Law (Heidelberg and Oxford University Press, 2012).

30) The prohibition of pillage applies to property. According to the Commentary to the Additional Protocols, p. 1376, this includes both State-owned and private property as well as immovable and movable property. In addition, the Nuremberg Tribunals have extended its scope to physical and intangible property. See the I.G. Farben case, Trials of War Criminals before the Nuremberg Military Tribunals under Control Council Law No. 10, vol. VIII (1952), p. 1134.

31) Elements of Crimes, Official Journal of the International Criminal Court, available at $<w w w$ .icc-cpi.int/library/about/officialjournal/Element_of_Crimes_English.pdf>, visited on 1 August 2012. See further K. Dörmann, Elements of War Crimes under the Rome Statute of the International Criminal Court: Sources and Commentary (International Committee of the Red Cross, Cambridge University Press, Cambridge, 2002). 
In this case, the DR Congo contended that members of the Ugandan army had systematically exploited the DRC's natural resources for their personal benefit. ${ }^{32}$ The International Court of Justice concluded that "whenever members of the UPDF were involved in the looting, plundering and exploitation of natural resources in the territory of the DRC", they acted in violation of the prohibition of pillage. ${ }^{33}$

However, fitting resource exploitation for the purpose of funding an armed conflict into the definition of pillage is far more problematic. An interpretation that confines pillage to the appropriation of natural resources for private or personal use seems to exclude from the definition of pillage the exploitation of natural resources for the purpose of funding an armed conflict.

This is at least true for the government that uses resource revenues to fund its military campaign. After all, military expenditure constitutes by definition a public purpose. For rebel groups this may be different. The application of pillage to resource exploitation by rebel groups for the purpose of funding an armed conflict may depend on the qualification of the armed struggle itself. Is the struggle ideologically motivated or is it primarily motivated by self-interest? This makes it a very difficult issue to deal with in abstracto.

Unfortunately, specific case law from modern international criminal tribunals applying the war crime of pillage to the exploitation of natural resources is lacking. Until now, none of these tribunals have applied the provision to instances of natural resource exploitation. Notwithstanding the potential of the war crime to capture these instances, counts of pillage before modern international criminal tribunals have been confined to the appropriation of personal belongings of civilians, mostly in relation to the raiding of villages. ${ }^{34}$ Even in the cases against Charles Taylor and the leaders of the RUF and the AFRC before the Special Court for Sierra Leone, where there was a close nexus between the exploitation of natural resources and the committing of other crimes, pillage of natural resources was not among the charges. ${ }^{35}$

In the absence of case law which may provide more specific guidance to the interpretation of pillage in relation to natural resources, it may be concluded in general that the prohibition of pillage applies first and foremost to the

32) Armed Activities on the Territory of the Congo (Democratic Republic of the Congo v. Uganda), I.C.J., 19 December 2005, Judgment, I.C.J. Reports 2005, paras. 222-229.

33) Ibid., para. 245 .

34) For examples of relevant practice by international criminal tribunals, see the ICRC Customary International Humanitarian Law Database, Rule 52, available through <www.icrc .org/customary-ihl/eng/docs/home>, visited on 27 January 2012.

35) For a detailed discussion of the crime of pillage and its applicability to the exploitation of natural resources, see L. J. van den Herik and D. A. Dam-de Jong, 'Revitalizing the Antique WarCrime of Pillage: The Potential and Pitfalls of Using International Criminal Law to Address Illegal Resource Exploitation During Armed Conflict', 22:3 Criminal Law Forum (2011) pp. $237-273$. 
exploitation of natural resources for purposes of self-enrichment. It seems less appropriate to apply the prohibition to exploitation for the purposes of funding an armed conflict. These instances may however be covered by the prohibition to destroy or seize the property of the adversary, which is discussed in the following section.

\subsubsection{Prohibition to Destroy or Seize the Property of the Adversary}

Whereas the prohibition of pillage relates to the appropriation of property for personal use, the prohibition on 'seizing' the property of the adversary relates to the appropriation of property for public purposes. This may be exemplified by the Commentary to the prohibition of pillage, which states that the latter prohibition "leaves intact the right of requisition or seizure". ${ }^{36}$ In addition, the Special Court for Sierra Leone has explicitly confirmed that 'seizure' relates to the appropriation of property for public purposes. ${ }^{37}$

In addition, the prohibition covers the destruction of property, bringing some forms of environmental damage within its ambit. Both the Special Court for Sierra Leone and the International Criminal Court have addressed instances of the burning of property as falling within the definition of destruction. ${ }^{38}$ This implies, for example, that the burning of parts of a forest to clear mining sites or for large-scale timber extraction may fall within the ambit of the prohibition.

The prohibition is based on Article 23(g) of the 1907 Hague Regulations, which formulates a prohibition on the destruction or seizure of enemy property unless imperatively demanded by the necessities of war. Unfortunately, an express provision for internal armed conflicts is lacking. Its applicability to internal armed conflicts may nonetheless be derived from Article 8(2)(e)(xii) of the ICC Statute, which criminalises the destruction and seizure of the property of an adversary.

However, the provision contains considerable impediments. A first relates to the condition that the property must belong to the adversary. This condition in fact limits the material scope of the war crime considerably. The question of ownership of natural resources is determined through national law. Many national constitutions vest the ownership of natural resources in the State. Therefore, the prohibition would primarily apply to rebel groups exploiting natural resources belonging to the State or to persons affiliated to the State.

Another impediment relates to the exception of military necessity. The prohibition on the destruction or seizure of the property of an adversary does not apply

\footnotetext{
36) J. Pictet and O. M. Uhler, The Geneva Conventions of 12 August 1949: commentary, Part 4 on the Geneva Convention relative to the protection of civilian persons in time of war, Geneva: International Committee of the Red Cross (1958), p. 227.

37) See The Prosecutor v. Moinina Fofana and Allieu Kondewa, Special Court for Sierra Leone, supra note 22, para. 392, note 770 .

38) The Prosecutor v. Moinina Fofana and Allieu Kondewa, supra note 22, para. 389. See further the Warrants of Arrest issued on 27 April 2007 by the ICC in the cases against Harun and Kushayb in relation to the conflict in Sudan.
} 
in cases of military necessity. In relation to natural resources, this prohibition may be understood as authorising acts of exploitation if strictly necessary to overcome the adversary. ${ }^{39}$ Although the exception of military necessity may thus only be invoked in extreme circumstances, it may not be ruled out entirely that the exception covers exploitation for the purposes of financing an armed conflict. This seems at least the case when resource revenues are used to satisfy the primary needs of members of armed groups, such as food, clothing and shelter.

Unfortunately, there is no relevant case law elaborating on these questions. Most of the existing case law with respect to the prohibition on the destruction or seizure of the property of an adversary relates to the destruction of property, in particular of houses and other property belonging to civilians. ${ }^{40}$

In conclusion, the prohibition on the destruction or seizure of the property of the adversary may be regarded as the counterpart of the prohibition of pillage. The latter formulates a prohibition for parties to an armed conflict to appropriate property for personal interests while the former relates to appropriation for public purposes. The prohibition on the destruction or seizure of the property of the adversary applies first and foremost to exploitation of natural resources by rebel groups. It prohibits exploitation unless there is a military necessity to do so. The scope of the prohibition thus depends in particular on the contents of the exception of military necessity in relation to the exploitation of natural resources.

\subsection{Peacetime Law}

The previous section demonstrated that international humanitarian law contains a few elementary rules relating to the exploitation of natural resources. These rules apply first and foremost to rebel groups exploiting natural resources. The rules seem less apt to cover the exploitation of natural resources by the domestic State in times of armed conflict, except when members of the national army exploit natural resources for their personal benefit.

However, this does not imply that a State is entitled to exploit the domestic natural resources as it sees fit. According to the general framework set out in section 3, peacetime law continues to apply, unless these rules are set aside by

39) Consider in this regard the Hostage case, where the Nuremberg Military Tribunal held in relation to the destruction of property that the Hague Regulations require the military necessity to be "urgent" and that there must be a "reasonable connection between the destruction of property and the overcoming of the enemy forces". The Tribunal also recognised that destruction as an end in itself is a violation of international law. Hostage case, Trials of War Criminals before the Nuernberg Military Tribunals Under Control Council Law No. 10, Nuremberg, October 1946-April 1949, Vol. XI, Washington: Government Printing Office (1959), pp. 1253-1254.

40) For examples of cases before criminal tribunals, see the ICRC Customary International Humanitarian Law Database under Rule 50, available through <www.icrc.org/customary-ihl/ eng/docs/home >, visited on 6 August 2012. 
more specific rules of international humanitarian law. In section 4.1 it was demonstrated that international humanitarian law does not contain specific rules to deal with natural resource exploitation by States participating in internal armed conflicts. Therefore, arguably, the peacetime framework for the exploitation of natural resources continues to apply in these circumstances.

The key rules that apply to the exploitation of natural resources by States ensue from the principle of permanent sovereignty over natural resources which is recognised by the International Court of Justice as a principle of customary law. ${ }^{41}$ Pursuant to this principle, natural resource ownership is vested within each State and people..$^{42}$ A government, as the legal representative of a State and its people, ${ }^{43}$ is thus entitled to exploit domestic natural resources.

Nonetheless, this right entails duties as well. ${ }^{44}$ First of all, States must exploit natural resources in a sustainable way. This condition ensues from the principle of sustainable use, which has been embodied in numerous international environmental treaties that qualify the rights of a State to dispose of their natural resources for the purposes of environmental protection. Suspension of the operation of these treaties - if possible at all - is not likely to affect the obligations contained therein, at least in as far as these treaties aim to protect the common interests of the international community. This is, for example, the case for the Convention on Biological Diversity, which qualifies the conservation of biological diversity as a "common concern of humankind".45 Thus, large scale logging "with little regard

41) See Armed Activities on the Territory of the Congo (Democratic Republic of the Congo v. Uganda), supra note 29, para. 244.

42) For a more thorough discussion of the principle of permanent sovereignty and the holders of the rights related to it, see Schrijver, supra note 21. For an analysis of the principle of permanent sovereignty over natural resources within the specific context of resource related armed conflicts, see P. N. Okowa, 'Natural Resources in Situations of Armed Conflict: Is there a Coherent Framework for Protection?', g International Community Law Review (2007) pp. 237-262; and D. A. Dam-de Jong, 'International Law and Resource Plunder: The Protection of Natural Resources during Armed Conflict', in O. K. Fauchald, D. Hunter and W. Xi (eds.), 19 Yearbook of International Environmental Law (Oxford University Press, Oxford, 2008) pp. 27-57.

43) A government is generally presumed to be the legal representative of a State, unless it is no longer recognised as such. In this regard it is interesting to mention the example of Libya. Not long after the beginning of the insurrection in February 2011, the international community started to recognise the insurrectional movement as the legitimate representative of the Libyan people and thus as the new government entitled to decide on the oil reserves of the country. This example shows that a government may lose its status as the legal representative of a State due to its course of actions during an armed conflict.

44) See Schrijver, supra note 21.

45) See the preamble of the Convention on Biological Diversity, adopted on 5 June 1992 (1760 UNTS 79) which "affirm[s] that the conservation of biological diversity is a common concern of humankind". Of course, there may be other impediments to observation of the obligations contained within such treaties. The Biodiversity Convention, for example, makes implementation 
to sustainable forest practices", such as happened in Liberia under Charles Taylor, is not permitted. ${ }^{46}$

Second, States must exploit the domestic natural resources for the benefit of the population. This condition ensues first of all from the Declaration on Permanent Sovereignty over Natural Resources. ${ }^{47}$ It has since been reaffirmed in several legal instruments, including resolutions of the Security Council dealing with the inter-linkage between natural resources and armed conflict. ${ }^{48}$ Of course, using the proceeds of resource exploitation to fight rebel forces may perfectly well fit into this description. However, a State that uses the proceeds of natural resource exploitation to commit gross human rights violations may be said to act contrary to the principle of permanent sovereignty over natural resources.

The armed conflict in Libya in 2011 provides a relevant example. During this conflict, the government of Libya, led by Colonel Qadhafi, carried out large-scale and systematic attacks against the civilian population. In response, the Security Council imposed an asset freeze against the Libyan authorities, which included the assets of the Libyan National Oil Corporation as a "potential source of funding for [Qadhafi's] regime". ${ }^{49}$

Furthermore, States must respect resolutions adopted by the Security Council, pursuant to Article 25 of the UN Charter. Some of these resolutions contain additional measures to be implemented by governments, restricting their right to freely dispose of the State's natural resources. ${ }^{50}$ Relevant measures include the establishment of a certificate of origin regime for natural resources, such as for rough diamonds originating from Sierra Leone and Liberia, or the implementation of a system aimed at promoting transparency and accountability in particular natural resources sectors, such as for the timber industry in Liberia. ${ }^{51}$ These measures are discussed in section 5 below.

of most of its obligations conditional on the conditions and capabilities of the implementing State.

46) Report of the Panel of Experts on Liberia established pursuant to Security Council Resolution 1343 (2001), paragraph 19, concerning Liberia, UN Doc. S/2001/1015 of 26 October 2001, para. 33 .

47) See the Declaration on Permanent Sovereignty over Natural Resources, UN General Assembly Resolution 1803 (XVII), adopted on 14 December 1962.

48) See e.g. UN Security Council Resolution 1457 (2003), operative para. 4; and Resolution 1521 (2003), operative para. 13 .

49) UN Security Council Resolution 1973 (2011), 17 March 2011, Annex II.

50) The measures are formulated as encouragements and not as hard legal obligations. However, due to the close connection between these measures and sanctions imposed against natural resources, they are to be regarded as imperative in nature. For examples, see section 4.2 of this article.

51) On diamonds, see UN SC Resolution 1306 (2000) for Sierra Leone and UN SC Resolution 1343 (2001) for Liberia. On timber, see UN Security Council Resolution 1521 (2003) on Liberia. 


\subsection{Appraisal of the Current Legal Framework for Resource Exploitation in Situations of Internal Armed Conflict}

It may be concluded from the above that the current regulatory framework dealing with the exploitation of natural resources by parties to an armed conflict is very fragmented. The prohibitions contained in international humanitarian law apply first and foremost to rebel groups, while States derive their obligations mostly from peacetime law.

In addition, the existing regulatory framework provides major loopholes for parties to an armed conflict. Examples of such loopholes include the definition of military necessity in relation to the prohibition on the destruction or seizure of the property of an adversary as well as the determination of what constitutes "for the benefit of the population" in relation to the exercise of permanent sovereignty over natural resources.

Related to these loopholes is the concern of legal uncertainty. The rules are not tailored to cover the specific situation of predatory resource exploitation. In the near absence of relevant case law, it is therefore extremely difficult to provide guidance in respect of the precise scope and contents of the rules in relation to the issue of predatory resource exploitation.

The judgment of the International Court of Justice in the DR Congo-Uganda case, which legally qualified the illicit exploitation of Congolese natural resources by Ugandan troops, may therefore be welcomed. This is especially so since the ICJ is the only international court which has explicitly addressed the issue of predatory resource exploitation in modern armed conflicts. However, this judgment touches upon some of the issues only. There is thus an urgent need to clarify the existing rules, both through case law and through codification and progressive development of these rules.

\section{Security Council Sanctions Regimes}

This section examines some of the sanctions regimes imposed by the Security Council in order to break the link between natural resources exploitation and the continuation of armed conflicts. The purpose of this section is twofold. First, it assesses the extent to which the sanctions regimes imposed by the Security Council provide a practical response to the imperfections of the regulatory framework discussed in the previous sections. Second, it assesses the role played by the Security Council in addressing the link between natural resources and armed conflict.

\subsection{General Remarks on Resource-Related Sanctions}

Sanctions are one of the most important tools of the UN Security Council to address threats to international peace and security. Pursuant to Article 41 of the 
UN Charter, the Security Council is entitled to take measures not involving the use of military force to maintain or restore international peace and security. The Council may do so in all phases of the conflict, once it has determined the existence of a threat to the peace, a breach of the peace or an act of aggression under Article 39 of the UN Charter.

Measures taken by the Security Council under Article 41 of the UN Charter prevail over the obligations of UN Member States under treaties to which they are party. ${ }^{52}$ For present purposes, this implies that Security Council sanctions may, for example, further restrict the rights of parties to an armed conflict under international humanitarian law. Likewise - and of the utmost importance for the cases discussed below - Security Council sanctions may qualify the right of a State to exercise permanent sovereignty over its natural resources if necessary to maintain or restore international peace and security.

Sanctions addressing predatory resource exploitation have generally targeted the trade in natural resources from regions where these natural resources have fuelled armed conflicts. In most cases, the Security Council has established Panels of Experts to make a factual assessment of the situation before imposing sanctions. Panel reports have extensively documented the role that natural resources played in the conflicts discussed in this article. In addition, their findings concerning the breaking of sanctions in particular conflicts, such as those in Angola and Sierra Leone, have been instrumental in the Security Council's embracing of new approaches to tackle the trade in 'conflict resources', such as through the Kimberley Process for the Certification of Rough Diamonds. ${ }^{53}$

Some of the sanctions regimes imposed by the Security Council in order to break the link between natural resources and armed conflict have directly addressed the trade in particular natural resources, while other sanctions regimes have rather targeted persons or entities involved in resource exploitation. Relevant examples of commodity sanctions include the diamond sanctions discussed below. Relevant examples of targeted sanctions include the asset freeze and travel ban targeting individuals or entities supporting armed groups in the DR Congo through illicit trade in natural resources"54 and the asset freeze against the Libyan National Oil Company during the 2011 Libyan civil war. ${ }^{55}$

This section focuses on two examples of structural approaches adopted by the Security Council in order to break the link between natural resources and armed conflict: certificate of origin schemes for particular commodities, and reform plans for the natural resources sector. In both cases, the Security Council has con-

52) Article 103 of the UN Charter determines that in the event of a conflict between the obligations of Members of the United Nations under the UN Charter and their obligations under any other treaty, their obligations under the Charter prevail.

53) See Section 4.2 for more details.

54) UN Security Council Resolution 1857 (2008), operative paragraph 4(g).

55) UN Security Council Resolution 1973 (2011), supra note 46. 
ditioned the lifting of sanctions upon the effective implementation of these measures.

In practice, the Security Council has resorted to the imposition of resource related sanctions in the phase of conflict resolution and has maintained these in the early stages of post-conflict reconstruction. The two approaches discussed in the current section are representative of the steps taken by the Security Council in this regard. Certification schemes are usually introduced in the phase of conflict resolution, while reform plans are generally introduced in the phase of post-conflict reconstruction.

\subsection{Certificate of Origin Schemes}

Certificate of origin schemes seek to prevent the trade in natural resources from fuelling armed conflict by providing a certificate for natural resources from which their origin can be established. To date there have been four instances in which the Security Council has turned to a certificate of origin scheme to exempt particular natural resources from a sanctions regime it has adopted. All address the trade in rough diamonds.

The first time the Security Council referred to a certificate of origin regime was in relation to the conflict in Angola. The diamond trade constituted one of the primary sources of income for the rebel movement UNITA. In order to end the violence in Angola, the Security Council decided in Resolution 1173 (1998) that all States must take the necessary measures "to prohibit the direct or indirect import from Angola to their territory of all diamonds that are not controlled through the Certificate of Origin regime of the [Angolan government]". ${ }^{56}$ In a subsequent resolution, the Security Council specified that the implementation of the measures contained in resolution 1173 requires "an effective Certificate of Origin regime". ${ }^{57}$

Also in relation to Sierra Leone, the Security Council installed a sanctions regime on all rough diamonds and requested the government of Sierra Leone "to ensure, as a matter of urgency, that an effective Certificate of Origin regime for trade in diamonds is in operation in Sierra Leone" which would exempt diamonds traded through this regime from the measures. ${ }^{58}$ In subsequent resolutions, the Security Council renewed the diamond sanctions but exempted diamonds controlled by the Certificate of Origin Regime that the government had put in place, to wit, the Kimberley Process certification scheme. ${ }^{59}$ The sanctions

56) Security Council Resolution 1173 (1998), operative para. 12(b).

57) Security Council Resolution 1295 (2000), operative para. 16.

58) Security Council Resolution 1306 (2000), operative paras. 1, 2 and 5 .

59) See Resolutions 1385 (2001) and 1446 (2002) for the extensions of the diamond sanctions. The Kimberley Process Certification Scheme is a voluntary mechanism to stop the trade in roughdiamonds that are used by non-State armed groups to finance their armed struggle. It was set up in 2002 by States, the diamond industry and non-governmental organisations in response to calls by the UN General Assembly and the Security Council for an international 
were finally lifted in 2003 in light of the government's "increased efforts to control and manage its diamond industry and ensure proper control over diamond mining areas, and the Government's full participation in the Kimberley Process".60

The third instance concerns the imposition of diamond sanctions against Liberia, principally to address the role of Liberia in the smuggling of Sierra Leonean diamonds. ${ }^{61}$ The Security Council demanded that the government of Liberia "cease all direct or indirect import of Sierra Leone rough diamonds which are not controlled through the Certificate of Origin regime of the Government of Sierra Leone" and called upon the government "to establish an effective Certificate of Origin regime for trade in rough diamonds that is transparent and internationally verifiable". ${ }^{62}$

In subsequent resolutions, adopted in the phase of post-conflict reconstruction, the Security Council went a step further. In Resolution 1478 (2003), the Security Council called upon the Liberian government "to establish a Certificate of Origin regime for Liberian rough diamonds that is transparent, internationally verifiable and fully compatible with the Kimberley Process". ${ }^{33}$ In a later resolution, the Security Council reiterated its call upon the government and encouraged it "to take steps to join the Kimberley Process as soon as possible". 64

Finally, in the case of Côte d'Ivoire, the Security Council installed a sanctions regime targeting the whole diamond industry in Côte d'Ivoire. ${ }^{65}$ These sanctions were imposed upon the request of the Ivorian government, which had already imposed a national ban on the export of diamonds in order to take away from the opposition forces their principal source of funding. ${ }^{66}$ In the same resolution, the Security Council expressly referred to the Kimberley Process. It welcomed the measures agreed by participants in the Kimberley Process Certification Scheme to prevent the export of all rough diamonds from the territory of Côte d'Ivoire and called upon the States in the region which are not participants in the Kimberley Process "to intensify their efforts to join the Kimberley Process in order to increase the effectiveness of monitoring the import of diamonds from Côte d'Ivoire". 67

certification scheme for rough diamonds. See e.g. UN General Assembly Resolution 55/56 of 29 January 2001. For more details on this Certification Scheme, see <www.kimberleyprocess. $\mathrm{com} />$, visited on 30 July 2012.

60) See UN Doc. SC/7778 of 5 June 2003 for a press statement by the president of the Security Council.

61) UN Security Council Resolution 1343 (2001), operative para. 6.

62) Ibid., operative paras. 2(c) and 15.

63) UN Security Council Resolution 1478 (2003), para. 13.

64) UN Security Council Resolution 1521 (2003), operative paras. 7 and 9.

65) UN Security Council Resolution 1643 (2005), operative para. 6.

66) Report of the Group of Experts submitted in accordance with paragraph 7 of resolution 1584 (2005), UN Doc. S/2005/699, para. 48.

67) UN Security Council Resolution 1643 (2005), operative para. 6. 
In response to political changes that took place in Côte d'Ivoire in 2011, the Security Council offered the Ivorian government an opportunity for the modification or lifting of sanctions. The Security Council conditioned the modification or lifting of the sanctions on the creation and implementation of an action plan by the Ivorian authorities to enforce the Kimberley Process rules in Côte d'Ivoire. ${ }^{68} \mathrm{~A}$ further condition stipulated that the authorities "closely work with the Kimberley Process Certification Scheme to conduct a review and assessment of Côte d'Ivoire's internal controls system for trade in rough diamonds and a comprehensive geologic study of Côte d'Ivoire's potential diamond resources and production capacity". 69

These resolutions reveal a growing tendency of the Security Council to use sanctions as a tool to provide structural solutions to break the link between natural resources and armed conflict. First of all, the resolutions develop standards for a certificate of origin scheme. In its resolutions concerning Angola and Sierra Leone, the Security Council asked for an effective regime to be set up. In its resolutions against Liberia, the Security Council elaborated upon this requirement by demanding that the Certificate of Origin regime must be transparent and internationally verifiable.

In addition, the Security Council has increasingly relied upon one particular certificate of origin scheme, the Kimberley Process Certification Scheme. Whereas in earlier resolutions the Council refers to the Kimberley Process as a model for an effective certificate of origin scheme, in later resolutions it refers to the Kimberley Process as the only viable option.

\subsection{Reform Plans for Natural Resources Sectors}

The Security Council has also used its powers under Chapter VII to set out reforms for particular natural resource sectors. The Liberian timber industry may serve as a primary example. After the diamond sanctions had been installed against Liberia, the government led by Charles Taylor increasingly resorted to logging as a means of generating revenue in order to finance the armed conflict in the region. Therefore, the Security Council called upon the government of Liberia to "take urgent steps, including through the establishment of transparent and internationally verifiable audit regimes, to ensure that revenue derived by the Government of Liberia from the ... Liberian timber industry is used for legitimate social, humanitarian and development purposes".70 Having no effect, the Security Council decided in a subsequent resolution to impose sanctions on Liberian timber. ${ }^{71}$

\footnotetext{
68) UN Security Council Resolution 2045 (2012), operative para. 6.

69) Ibid., operative para. 21.

70) UN Security Council Resolution 1408 (2002), operative para. 10.

71) UN Security Council Resolution 1478 (2003), operative para. 16.
} 
After Charles Taylor had been ousted from power, these sanctions remained in place as part of the post-conflict reconstruction phase. In Resolution 1521 (2003), the Security Council urged the government of Liberia "to establish its full authority and control over the timber producing areas, and to take all necessary steps to ensure that government revenues from the Liberian timber industry are not used to fuel conflict or otherwise in violation of the Council's resolutions but are used for legitimate purposes for the benefit of the Liberian people, including development". ${ }^{72}$ It also encouraged the government "to establish oversight mechanisms for the timber industry that will promote responsible business practices, and to establish transparent accounting and auditing mechanisms to ensure that all government revenues ... are not used to fuel conflict or otherwise in violation of the Council's resolutions but are used for legitimate purposes for the benefit of the Liberian people, including development". ${ }^{73}$ Moreover, these objectives include "the promotion of responsible and environmentally sustainable business practices in the timber industry". ${ }^{74}$

In order to implement the measures set out in resolution 1521 (2003), the Liberian government developed two programmes with the aid of other States and international organisations. The first concerns the Liberia Forest Initiative, aimed at improving transparency and accountability for timber revenues as well as sustainable forest management. ${ }^{75}$ The second programme, the Governance and Economic Management Assistance Program (GEMAP), has a more general scope and is aimed at improving transparency and accountability in government revenues and expenditure. ${ }^{76}$

In Resolution 1647 (2005), the Security Council embraced both programmes. With respect to the forest initiative, the Security Council considered that its implementation would "ensure transparency, accountability and sustainable forest management and contribute towards the lifting of the measures on timber in accordance with paragraphs 11 and 12 of resolution 1521 (2003)". ${ }^{77}$ Likewise, the Security Council encouraged the government of Liberia to implement the Governance and Economic Management Assistance Program which would "expedite the lifting of the measures imposed by resolution 1521 (2003)".78

These resolutions reveal a tendency of the Security Council to expand its tasks with regard to the maintenance of international peace and security. The resolutions in relation to Liberia go far beyond direct crisis management. The Security

72) UN Security Council Resolution 1521 (2003), para. 11.

73) Ibid., para. 13.

74) Ibid., para. 15 .

75) For more information on this initiative, see the website of the UN Food and Agriculture Organization, at <www.fao.org/forestry/lfi/en/>, visited on 30 January 2012.

76) The GEMAP document is available through the website of the World Bank, at < siteresources .worldbank.org/LIBERIAEXTN/Resources/GEMAP.pdf>, visited on 30 January 2012.

77) UN Security Council Resolution 1647 (2005), operative para. 3.

78) UN Security Council Resolution 1647 (2005), operative para. 4. 
Council asks for great structural reforms and makes the lifting of sanctions conditional upon effective implementation of these reforms. In addition, it sets all kinds of requirements with respect to the contents and objectives of these reform programmes. The programmes must establish transparent and internationally verifiable audit regimes; they must promote responsible and environmentally sustainable business practices; and they must ensure that government revenues are used for legitimate social, humanitarian and development purposes for the benefit of the Liberian people. In this way, the Security Council has contributed in a more structural way to efforts of peace-building in Liberia, ensuring that Liberian natural resources are managed in a sustainable way for the purpose of development rather than conflict.

\section{Adequacy of the Overall Legal Framework}

This article has examined the role played by current international law in addressing the problem of predatory resource exploitation by parties to an armed conflict. It has discussed the regulatory framework applicable to the exploitation of natural resources in internal armed conflicts and has examined the practice of the Security Council in relation to armed conflicts fuelled through resource revenues. In particular, it has analysed two of the more systematic approaches of the Council's recent sanctions regimes to break the link between natural resources and armed conflict.

From the analysis above it is clear that the current regulatory framework for the exploitation of natural resources during internal armed conflicts is fragmented. International humanitarian law deals principally with obligations for rebel groups, while States derive most of their obligations from peacetime law. Especially relevant in this regard are international environmental, human rights and general international law. This fragmentation of obligations under international law creates uncertainties with regard to the applicable law.

In addition to being fragmented, the current regulatory framework is imprecise, leading to uncertainties regarding the interpretation of the obligations themselves. Notions such as 'military necessity', the distinction between exploitation for public and for private purposes and a determination of what constitutes exploitation "for the benefit of the population" create uncertainties with regard to the substantive obligations of parties to an armed conflict.

Uncertainties within the regulatory framework, whether they result from questions concerning the applicable law or from the nature and scope of the substantive obligations, are problematic in situations of armed conflict. These situations call for clear and unequivocal rules for both sides to the conflict. This would increase the likelihood of the parties to an armed conflict respecting the rules. 
In order to address these inadequacies, the existing legal framework thus needs to be clarified and, preferably, expanded.

As discussed above, the Security Council has found ways to address the problem of predatory resource exploitation in a more structural way in the past decades through the use of sanctions and, in particular, by tying the modification or lifting of sanctions to the implementation of certificate of origin regimes and reform plans for particular natural resources sectors. One of the advantages of sanctions regimes is that these can be imposed against all parties to an armed conflict, without touching directly upon questions concerning the legality of resource exploitation. There may, for example, be good reasons for the Security Council to impose sanctions upon a party to an armed conflict, while the resource exploitation itself is perfectly legal. In addition, the prospect of the lifting of sanctions may pose an incentive to States to engage in structural reforms of their natural resource sectors. These structural reforms not only reduce the likelihood for that country to relapse into conflict but they may also help to turn natural resources into an engine for sustainable development.

In sum, it is only through a combination of different approaches that the link between the exploitation of natural resources and armed conflict can properly be addressed. The sanctions regimes imposed by the Security Council may provide solutions to particular instances where natural resources are used to fund an armed conflict. One of the most important advantages of sanctions regimes is that they can be tailored to address specific situations. Nonetheless, dealing with the issue of predatory resource exploitation in such an ad hoc manner is not sufficient. It is also of the utmost importance to provide parties to an armed conflict with clear rules to which they can adhere. This may not, in itself, put an end to the exploitation of natural resources for the purposes of funding an armed conflict. However, in the long run, it may significantly enhance the possibilities of turning natural resources from engines for conflict into engines for sustainable development. 
